\title{
An Investigation on the R\&D Expenditures in Turkey: A Firm-Level Approach
}

\author{
Mehmet Fatih Traş ${ }^{1}$ Esra Ballı ${ }^{1} \&$ Çiler Sigeze ${ }^{1}$ \\ ${ }^{1}$ Faculty of Economics and Administrative Sciences, Çukurova University, Adana, Turkey \\ Correspondence: Esra Ballı, Faculty of Economics and Administrative Sciences, Çukurova University, Adana, \\ Turkey. Tel: 90-322-338-6084. E-mail: esraballi@cu.edu.tr
}

Received: January 31, 2016

Accepted: February 25, 2016

Online Published: April 25, 2016

doi:10.5539/ijef.v8n5p48

URL: http://dx.doi.org/10.5539/ijef.v8n5p48

\begin{abstract}
Access to foreign technology is important for small and medium sized companies. Most small and medium sized firms face with constraints resulting from financial, institutional and structural issues. In developing countries, most firms tend not to invest in Research and Development (R\&D), resulting in lack of innovation. Besides, $R \& D$ is important to enter in international markets, in the determination of firm's competition level, sustaining growth as well as to obtain a more advanced technology. Therefore, exhibiting the factors determining R\&D level for companies becomes crucial to make well-targeted policies both in government and firm levels. This study aims to analyze the participation and expenditure decisions of Turkish manufacturing firms in R\&D activities employing Heckman selection model taking region and industry effects into consideration. The results demonstrate that human capital, government funding of R\&D and the scale of the firm are related to R\&D decisions.
\end{abstract}

Keywords: R\&D decision, Heckman selection model, Turkey

\section{Introduction}

The importance of the technology and innovation is widely accepted in economic development literature. Schumpeter (1934) made significant contributions to this field. Schumpeter (1934) identified innovation as the main source of the economic development and defined the process "creative destruction" referring to a dynamic process in which new technologies replaces the old one. Schumpeter (1934) listed the following five types of innovations. These are the introduction of new products, introduction of new methods of production, opening of new markets, development of new sources of supply for raw materials or other inputs and creation of new market structures in an industry. In this manner, the firms would increase their research and development expenditures to innovate and capture a new market.

Most scholars state that research and development expenditures play an important role in stimulating R\&D activities. Considering governmental research and development expenditures as a percentage of GDP an increasing trend is observed. Latest figures (2013) extracted from World Bank show that research and development expenditures as a percentage of GDP of Denmark, Finland, Israel, Japan, Norway, Switzerland, Turkey, United States and United Kingdom are 3.02\%, 3.41\%, 4.24\%, 3.34\%, 1.62\%, 2.96\%, $0.92 \%, 2.80 \%$ and $1.63 \%$, respectively. As we seen from the figures advanced countries allocate more resources to R\&D. Therefore, it is important for developing countries like Turkey to determine the factors influencing the R\&D expenditures.

The rest of the paper is organized as follows. The second section presents the latest developments in Turkish economy. The third section discusses literature review. The fourth section presents the empirical strategy. The fifth section shows the data. The sixth reports empirical results and the seventh section concludes.

\section{Turkish Economy}

Starting from 1980s Turkey accepted export-oriented policy to liberalize the Turkish economy. With the introduction of this policy government indented to boost and support private sector. However this attempt failed and led to high fiscal deficit and high inflation rates dominated the economy. As a result, economy lost momentum and exhibited a weak performance in the late 1980s. Furthermore, government was unsuccessful in decreasing budget deficit. After experiencing financial crisis in 1994 in which an extreme depreciation in exchange rate occurred, government sought for a financial aid from both the International Monetary Fund (IMF) 
and the World Bank. However, structural reforms in the fields of banking, energy, pension system were not fulfilled in the frame of IMF and World Bank programs. These imperfections paved the way of serious problems in the future.

Asian and Russian financial crises in 1998, deeply affected Turkish economy and eroded the confidence of consumers and investors in the economy. To put economy on the right path, government implemented an IMF-monitored program with measures aiming to decrease inflationary expectations, in an attempt to lower real interest rates and redeem the government debt's payment interest rates. However, the decrease in interest rates overheated the economy through the channels of consumption and sharp growth in imported goods. Failed fiscal discipline, government delay in intervention, and commercial banks' liquidity problems combined with unstable political atmosphere led to 2001 financial crisis. The largest financially aid IMF program was set up to reach a recovery in the economy. With this program and austerity measures a continuous growth rate starting from 2002 till global financial crisis emerged in 2008 was achieved (World Bank in Turkey, 1993-2004: an IEG Country Assistance Evaluation). However, this interruption in 2009 was quickly recovered by means of strong capital inflows and abundance of credits (OECD Economic Surveys: Turkey 2014).

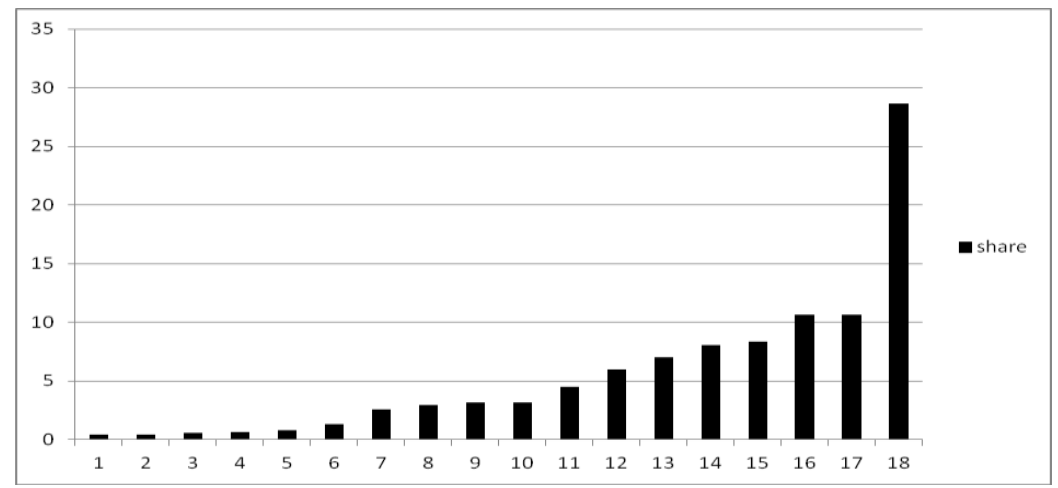

Figure 1 . The R\&D expenditure shares by industry in Turkey

Figure 1 represents the R\&D expenditure shares by industry in Turkey. The data extracted from OECD (2014). The corresponding subgroup respectively are (1) Manufacture of coke and refined petroleum products; (2) Manufacture of wood, paper, printing and reproduction; (3) Repair and installation of machinery and equipment; (4) Manufacture of furniture; (5) Other manufacturing; (6) Manufacture of basic metals; (7) Manufacture of other non-metallic mineral products; (8) Manufacture of food products; beverages and tobacco products (9) Manufacture of rubber and plastic products (10) Manufacture of textiles, wearing apparel, leather and related products; (11) Manufacture of basic pharmaceutical products and pharmaceutical preparations; (12) Manufacture of computer, electronic and optical products; (13) Manufacture of chemicals and chemical products; (14) Manufacture of fabricated metal products, except machinery and equipment; (15) manufacture of machinery and equipment n.e.c.;(16) Manufacture of electrical equipment; (17) Manufacture of other transport equipment; (18) Manufacture of motor vehicles, trailers and semi-trailers. Figure 1 shows that R\&D expenditure in Turkey is dominated by motor vehicles, trailers, transport and electrical equipment industries.
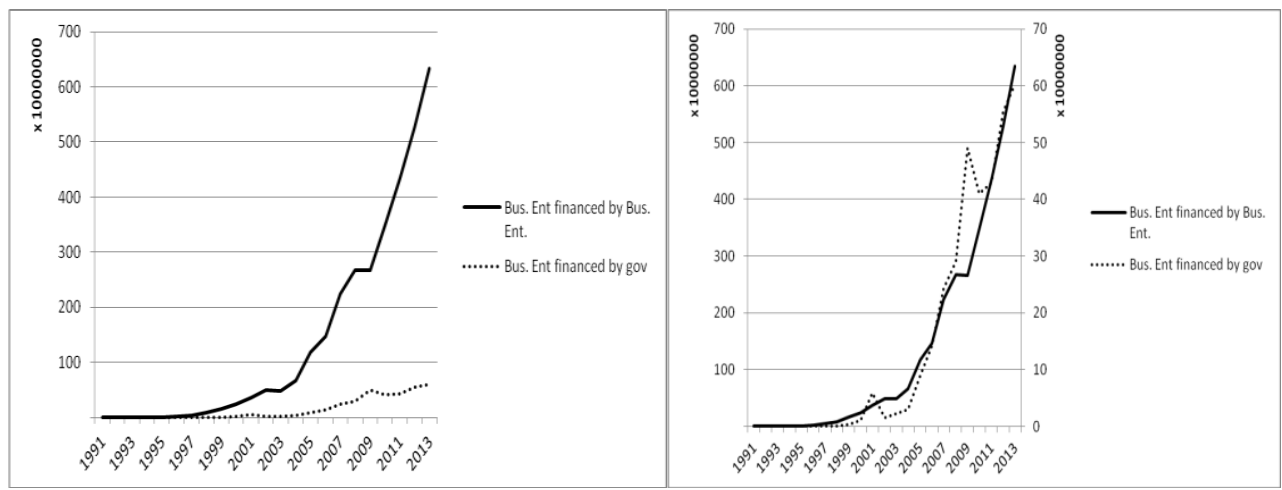

Figure 2. Privately and publicly funded R\&D activities performed by business enterprisers in Turkey 
Figure 2 exhibits privately and publicly funded R\&D activities performed by business enterprises in Turkey. As can be seen on the left panel of Figure 2 private R\&D expenditures financed by Business Enterprisers and Government show an upward trend during 1991-2013. The right side of Figure 2 provides a more careful inspection of the series using different scales. While privately funded R\&D activities performed by business enterprises far outperforms publicly funded R\&D activities over the same period.

\section{Literature Review}

The majority of the empirical studies have agreed that R\&D plays an important role in the firm's productivity. Hall and Mairesse (1995) investigated the role of R\&D on productivity for French manufacturing firms and reported that a sustained $R \& D$ expenditures causes productivity gains. Crépon et al. (1998) confirming Hall and Mairesse (1995), finds a positive correlation between R\&D and productivity. Griffith (2003) also investigated whether R\&D expenditures enable firms to utilize from discoveries and concluded that R\&D affects both innovation and the ability of adapting newly introduced technologies of the companies in the same sector. Correspondingly, Roper and Love (2002) reported that while UK and German manufacturing establishments are differing in the determinants of export performance, product innovation is found to have profound effect on probability and propensity to export in both countries. Besides, they also agree that innovative and non-innovative establishments display differences in their ability of absorption of spill-over effects.

Limanl (2015) examined the determinants of research and development decision in Turkey for 2008 and 2013 utilizing Generalized Linear Mixed Model for Complex Survey Design approach and found that sales, subsidy, share of foreign ownership, competition incentive, scale of enterprise, domestic and foreign trade shares are significantly important factors for investment on R\&D. Aerts and Schmidt (2008) investigated the role of public $R \& D$ subsidies on $R \& D$ decisions for Flemish and German companies and found that supported firms are significantly more R\&D willing than non- supported firms. Lööf and Hesmati (2004) also indicated that public $R \& D$ funding is efficient in terms of stimulating higher $R \& D$ investment of the firms. Özçelik and Taymaz (2008) examined the determinants of private R\&D investment focusing on the effect of public R\&D support programs and concluded that publicly funded R\&D has significant and positive impact and small firms enjoy R\&D support to higher extent and therefore, these firms initiate more R\&D activities. De Negri et al. (2006) examined the impact of Brazilian National Technological Development Support Program (ADTEN) on the Brazilian manufacturers and found that this R\&D program provided support to a quite limited number of firms while this program did have positive impact on the R\&D decisions of private companies (Note 1). Rajan and Zingales (1998) examined the influence of financial development on industrial sectors and found that financial deepening markets allow firms to reach less costly external financial sources. Hyytinen and Toivanen (2005) indicated that there was evidence that financial constraints curb innovation and growth, public policy can be used as a cope mechanism against these limitations. Clausen (2009) investigated the impact of "research" and "development" subsidies on private R\&D and presented that "research" and "development" subsidies trigger higher R\&D spending. González and Pazó (2008) analyzed the influence of public R\&D findings on private $R \& D$ decision. The results show that without subsidies, small firms operated in low technology sectors cannot conduct R\&D activities. Klette and Møen (1998) discussed the effect of governmental support on R\&D for Norwegian manufacturing sectors especially for information technology (IT) and revealed that despite above average support compared to OECD countries, R\&D expenditure does not exhibit a significant variation for the supported firms and the non-supported firms in the IT industries. Klette et al (2000) provides a comprehensive survey on the influence of governmental support program for R\&D activities. Almus and Czarnitzki (2003) investigated the influence of public R\&D support on the innovation activities in Eastern Germany firms and as a result concluded that firms increase their innovations.

\section{Empirical Strategy}

Since firms self-select into R\&D or non-R\&D decisions, we utilize Heckman's (1976) two-stage estimation method to investigate the determinants of $R \& D$. In so doing, we set up the first stage probit regression as follows Selection Equation:

$$
\begin{gathered}
R \& D^{*}=w_{1} \gamma_{1}+u_{1} \quad u_{1} \sim \mathrm{N}\left(0, \sigma^{2}\right) \\
R \& D=1 \text { if } R \& D^{*}>0 \\
R \& D=0 \text { if } R \& D^{*} \leq 0
\end{gathered}
$$

In the first stage (selection equation) we estimate whether firms decide to invest in R\&D or not. In the second stage, the level of $R \& D$ is investigated, for a given firm participating into R\&D activity. 
Intensity Equation:

$$
R \& D_{\text {int }}=w_{2} \gamma_{2}+u_{2} \quad u_{2} \sim \mathrm{N}\left(0, \sigma^{2}\right)
$$

where $R \& D_{\text {int }}$ is observed if and only if $R \& D=1$. Following Guo et al (2014) the variable $R \& D^{*}$ is the latent $R \& D$ decision variable, $w_{1}$ and $w_{2}$ are vector of explanatory variables determining for $R \& D$ decision and $R \& D$ intensity, respectively. $\gamma_{1}$ and $\gamma_{2}$ are vectors of parameters. $u_{1}$ and $u_{2}$ are error terms of the two regression equations, and are assumed to be bivariate normal, with mean zero and covariance matrix $\left[\begin{array}{cc}\sigma_{\varepsilon} & \rho \\ \rho & 1\end{array}\right]$.

Sole estimation of the intensity equation results in biased parameter estimator for the sample chosen may not be totally random which is conventionally known as selection bias. To avoid this problem we utilized Heckman's (1979) two-step method to estimate Model (1) and (2). Table 1 shows descriptive statistics and definitions of the variables.

Table 1. Variable definitions and summary statistics

\begin{tabular}{llll}
\hline Variable & Definitions & mean & std. Dev. \\
\hline RDI & R\&D intensity: the ratio of R\&D expenditure to total sales (\%) & 0.12 & 0.855 \\
KL & Capital intensity: total sales per employee & 578285.800 & 9514300 \\
SIZE & Total sales & 30829150.1 & 204858036.1 \\
SKILL & Ratio of university graduates to total employees & 10.52 & 14.719 \\
EXPI & Export intensity: the ratio of export expenditure to total sales (\%) & 0.119 & 0.855 \\
DMNC & Dummy Foreign ownership: Dummy variable equals 1 if firm has foreign ownersip & 0.051 & 0.222 \\
DEXP & Dummy Export: Dummy variable equals 1 if firm has performed export & 0.545 & 0.498 \\
GovSupport & If the firm has received any supports from the national, regional or local & 0.111 & 0.314 \\
& governments or European Union sources within last three years & & 12.588 \\
AGE & Age of the firm & 18.858 & 12 \\
\hline
\end{tabular}

\section{Data}

In this study we use the data from the World Bank's Turkey-Enterprise Survey conducted in 2013 and 2014 in a cross-section study through face-to-face interviews with the establishments. In this survey total number of samples selected based on industry, establishment size and region stratification is 1344 . However, after omitting observations with missing and outlier responses on the variables involved in the empirical model, we end up with the sample size of 693. The advantage of the data used in this study lies in that it constitutes the most recent sample set available, reflecting the behaviors of firms from different dimensions such as industry, establishment size and regions in Turkey.

\section{Empirical Results}

Table 2 reports parameters estimated by Heckman two-step selection model and the signs and magnitudes of most of the parameters are consistent with theoretical expectations. Out of 693 observations only 43 firms have positive $R \& D$ expenditure. For a better assessment of the determinants of $R \& D$ participation and level of expenditure decision we estimate three models: Model 1 shows the pure Heckman selection estimates for all sample while Model 2 and Model 3 control for region and industry effects, respectively.

The coefficient of the size variable measured in terms of total sales is estimated to have a positive impact on $R \& D$ decision whereas the effect of this variable on level of expenditure turns out to be negative. This finding is consistent with the results of Limanlı (2015). It indicates that larger firms are more inclined to participate into $R \& D$ activity relative to smaller firms. However, smaller firms conduct a higher R\&D activity, once they participate into R\&D activity in Turkey. This finding highlights the importance of cope mechanisms developed against obstacles and barriers in R\&D activity participation.

Capital intensity variable has insignificant impact on both R\&D participation and level of expenditure decisions. On the other hand, dummy variable for exporting firms indicates a positive and statistically significant association with $R \& D$ intensity decision, albeit it has no significant effect on $R \& D$ participation decision. According to the models, skill variable has positive effect on $R \& D$ participation decision, while its effect on 
level of R\&D expenditure is statistically significant only in industry-corrected model. Besides, the coefficient of the age of establishment has statistically significant negative effect on R\&D participation decision in industry-corrected model, implying that younger firms are more likely to initiate R\&D activities. Foreign ownership variable is insignificant in all models except for industry-corrected model.

Dummy variable for governmental support has positive and statistically significant effect on R\&D participation decision in all three models estimated. This result is consistent with the results of Özçelik ve Taymaz (2008), Aers and Schmidt (2008) and Lööf and Hesmati (2004) and Clausen (2009). Once government supports R\&D participation, firms are inclining to more initiate in R\&D activities. Additionally, this finding is particularly meaningful considering the contracting effects found in firm size variable, suggesting that smaller firms are more likely to have higher $R \& D$ expenditure once they participate into $R \& D$ activities. Accordingly, this finding signals that governmental support for small firms in particular can be employed as a cope mechanism against the obstacles posing limitations on small firms to take R\&D conduct decision in Turkey.

Table 2. Determinants of R\&D activities (1994-2001) Heckman two-step selection model estimation results

\begin{tabular}{|c|c|c|c|c|c|c|}
\hline & \multicolumn{2}{|c|}{ Model 1} & \multicolumn{2}{|c|}{ Model 2(region) } & \multicolumn{2}{|c|}{ Model 3(industry) } \\
\hline & R\&D Intensity & $\mathrm{R} \& \mathrm{D}$ decision & R\&D Intensity & R\&D decision & R\&D Intensity & $\mathrm{R} \& \mathrm{D}$ decision \\
\hline \multirow[t]{2}{*}{ Constant } & $21.052^{* * *}$ & $-2.887^{* * *}$ & $21.052 * * *$ & $-2.887 * * *$ & $21.052^{* * *}$ & $-2.887 * * *$ \\
\hline & $(6.383)$ & $(0.676)$ & $(7.311)$ & $(0.887)$ & $(0.287)$ & $(0.335)$ \\
\hline \multirow[t]{2}{*}{ Lntotalsales } & $-2.102 * *$ & $0.273^{*}$ & $-2.102 * * *$ & $0.273 * * *$ & $-2.102 * * *$ & $0.273^{* * *}$ \\
\hline & $(0.888)$ & $(0.145)$ & $(0.634)$ & $(0.099)$ & $(0.679)$ & $(0.061)$ \\
\hline \multirow[t]{2}{*}{$\operatorname{lnKL}$} & -0.386 & -0.115 & -0.386 & -0.115 & -0.386 & -0.115 \\
\hline & (1.124) & $(0.174)$ & $(1.241)$ & $(0.144)$ & $(0.939)$ & $(0.119)$ \\
\hline \multirow[t]{2}{*}{ DEXP } & $1.988^{* *}$ & -0.109 & $1.988 * * *$ & -0.109 & $1.988 * * *$ & -0.109 \\
\hline & $(0.965)$ & $(0.178)$ & $(0.667)$ & $(0.252)$ & $(0.252)$ & $(0.141)$ \\
\hline \multirow[t]{2}{*}{ SKILL } & -0.022 & $0.014 * * *$ & -0.022 & $0.014 * * *$ & $-0.022 * * *$ & $0.014 * * *$ \\
\hline & $(0.025)$ & $(0.004)$ & $(0.019)$ & $(0.002)$ & $(0.006)$ & $(0.001)$ \\
\hline \multirow[t]{2}{*}{ LnAGE } & 1.977 & -0.077 & 1.977 & -0.077 & $1.977^{* *}$ & $-0.077^{*}$ \\
\hline & (1.668) & $(0.267)$ & $(2.422)$ & $(0.385)$ & $(0.774)$ & $(0.044)$ \\
\hline \multirow[t]{2}{*}{ DMNC } & -1.312 & -0.510 & -1.312 & -0.510 & $-1.312 * *$ & $-0.510 * * *$ \\
\hline & $(2.200)$ & $(0.389)$ & (2.413) & $(0.489)$ & $(0.591)$ & $(0.012)$ \\
\hline \multirow[t]{2}{*}{ GovSupport } & & $0.699 * * *$ & & $0.699 * * *$ & & $0.699 * * *$ \\
\hline & & $(0.179)$ & & $(0.195)$ & & $(0.027)$ \\
\hline \multirow[t]{2}{*}{ Lambda } & -3.283 & & -3.283 & & -3.283 & \\
\hline & $(1.170)$ & & (1.613) & & $(0.702)$ & \\
\hline Wald chi2 & $15.41^{* *}$ & & & & & \\
\hline Number of observations & 693 & & 693 & & 693 & \\
\hline Number of R\&D Performers & 43 & & 43 & & 43 & \\
\hline
\end{tabular}

Figures in the parentheses are standard deviations, ***, ** and * denote coefficient are significant at $1 \%, 5 \%$, and $10 \%$ statistical levels, respectively.

\section{Discussion}

This study investigates the participation and expenditure decisions of Turkish manufacturing firms in R\&D activities using data from the World Bank's Turkey-Enterprise Survey conducted in 2013 and 2014 in a cross-section study through face-to-face interviews with the establishments. Turkey accepted export-oriented policy to liberalize the Turkish economy from 1980s. Despite government indented to boost and support private sector, R\&D has sustained decent degree, ranking quite low levels in terms of R\&D expenditure, technology, innovation among OECD countries.

Given the span of data set and econometric techniques employed, according to the results, some firm-specific variables such as export status, skill, and the age of establishments have effect on the R\&D decision in Turkey. Among these, the size of establishments plays an important role in determination of R\&D in Turkey. As can be expected, larger firms are more likely to participate into R\&D activities. However, smaller firms participating into $R \& D$ tend to allocate more resources to $R \& D$ in Turkey. This finding highlights the importance of cope mechanisms developed against obstacles and barriers in R\&D activity participation. On the other hand, governmental support encourages firms to participate into R\&D. It can be argued that, government support is 
crucial to carry out $R \& D$ which in turn would allow firms to generate technology and compete in international markets. Accordingly, this finding signals that governmental support for small firms in particular can be employed as a cope mechanism against the obstacles posing limitations on small firms to take R\&D conduct decision in Turkey.

\section{References}

Aerts, K., \& Schmidt, T. (2008). Two for the price of one? Additionality effects of R\&D subsidies: A comparison between Flanders and Germany. Research Policy, 37(5), 806-822. http://dx.doi.org/10.1016/j.respol.2008.01.011

Almus, M., \& Czarnitzki, D. (2003). The effects of public R\&D subsidies on firms' innovation activities: The case of Eastern Germany. Journal of Business \& Economic Statistics, 21(2), 226-236. http://dx.doi.org/10.1198/073500103288618918

Clausen, T. H. (2009). Do subsidies have positive impacts on R\&D and innovation activities at the firm level?

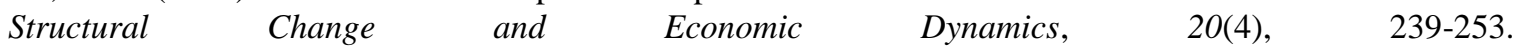
http://dx.doi.org/10.1016/j.strueco.2009.09.004

Crépon, B., Duguet, E., \& Mairessec, J. (1998). Research, Innovation And Productivity: An Econometric Analysis At The Firm Level. Economics of Innovation and New technology, 7(2), 115-158. http://dx.doi.org/10.1080/10438599800000031

De Negri, J. A., Lemos, M. B., \& De Negri, F. (2006). Impact of $P \& D$ Incentive Program on the Performance and Technological Efforts of Brazilian Industrial Firms. Inter-American Development Bank.

González, X., \& Pazó, C. (2008). Do public subsidies stimulate private R\&D spending? Research Policy, 37(3), 371-389. http://dx.doi.org/10.1016/j.respol.2007.10.009

Griffith, R., Redding, S., \& Van Reenen, J. (2003). R\&D and absorptive capacity: Theory and empirical evidence. The Scandinavian Journal of Economics, 105(1), 99-118. http://dx.doi.org/10.1111/1467-9442.00007

Guo, S., \& Fraser, M. W. (2014). Propensity score analysis: Statistical methods and applications (Vol. 11). Sage Publications.

Hall, B., \& Van Reenen, J. (2000). How effective are fiscal incentives for R\&D? A review of the evidence. Research Policy, 29(4), 449-469. http://dx.doi.org/10.1016/S0048-7333(99)00085-2

Heckman, J. J. (1976). The Common Structure of Statistical Models of Truncation, Sample Selection and Limited Dependent Variables and a Simple Estimator for Such Models. Annals of Economic and Social Measurement, 5, 475-92.

Hyytinen, A., \& Toivanen, O. (2005). Do financial constraints hold back innovation and growth? Evidence on the role of public policy. Research Policy, 34(9), 1385-1403. http://dx.doi.org/10.1016/j.respol.2005.06.004

Klette, T. J., \& Møen, J. (1998). From growth theory to technology policy: Coordination problems in theory and practice. Norwegian School of Economics and Business Administration.

Klette, T. J., Møen, J., \& Griliches, Z. (2000). Do subsidies to commercial R\&D reduce market failures? Microeconometric evaluation studies. Research Policy, 29(4), 471-495. http://dx.doi.org/10.1016/S0048-7333(99)00086-4

Limanl1, Ö. (2015). Determinants of R\&D Investment Decision in Turkey. Procedia-Social and Behavioral Sciences, 195, 759-767. http://dx.doi.org/10.1016/j.sbspro.2015.06.471

Lööf, H., \& Hesmati, A. (2004). The Impact of Public Funding on Private R\&D investment: New Evidence from a Firm Level Innovation Study (Additionality or Crowding Out? On the effectiveness of R\&D subsidies)

OECD. (2014). OECD Economic Surveys: Turkey 2014. OECD Publishing. http://dx.doi.org/10.1787/eco_surveys-tur-2014-en

Özçelik, E., \& Taymaz, E. (2008). R\&D support programs in developing countries: The Turkish experience. Research Policy, 37(2), 258-275. http://dx.doi.org/10.1016/j.respol.2007.11.001

Rajan, R. G., \& Zingales, L. (1998). Financial dependence and growth. American Economic Review, 88, 559-587.

Roper, S., \& Love, J. H. (2002). Innovation and export performance: Evidence from the UK and German $\begin{array}{lllll}\text { manufacturing plants. } & \text { Research } & \text { 1087-1102. }\end{array}$ http://dx.doi.org/10.1016/S0048-7333(01)00175-5 
Schumpeter, J. A. (1934). The theory of economic development: An inquiry into profits, capital, credit, interest, and the business cycle (Vol. 55). Transaction publishers.

World Bank Enrerprise Survey Report. (2013). Retrieved from http://www.enterprisesurveys.org/ /media/GIAWB/EnterpriseSurveys/Documents/CountryHighlights/Turke y-2013.pdf

World Bank in Turkey. (2006). World Bank in Turkey, 1993-2004: An IEG Country Assistance Evaluation (Vol. 1). $\quad$ Retrieved from http://www-wds.worldbank.org/external/default/WDSContentServer/IW3P/IB/2006/06/27/000160016_200 60627172521/Rendered/PDF/365840TR0see0also03478301PUBLIC1.pdf

\section{Note}

Note 1. For more detailed literature discussion see Hall and Reenen (2000) and the references cited therein.

\section{Copyrights}

Copyright for this article is retained by the author(s), with first publication rights granted to the journal.

This is an open-access article distributed under the terms and conditions of the Creative Commons Attribution license (http://creativecommons.org/licenses/by/3.0/). 